\title{
IMPACT ANALYSIS OF INTERNAL CATALYST CONVERTER ON OPERATING PARAMETERS OF VW 1.9 TDI ENGINE
}

\author{
Piotr Haller \\ Wroclaw University of Technology \\ Faculty of Mechanical Engineering \\ Wyspianskiego Street 27, 50-370 Wroclaw, Poland \\ tel.: +48713477918, fax: +48713477918 \\ e-mail:piotr.haller@pwr.wroc.pl \\ Antoni Jankowski \\ Institute of Aviation \\ Krakowska Av. 110/114 02-256 Warsaw, Poland \\ tel.:+48228460011; fax: +48228464432 \\ e-mail:ajank@ilot.edu.pl
}

\begin{abstract}
The largest amount of air pollutants is produced by the combustion of fossil fuels (coal, lignite, petroleum, natural gas, etc.). Such combustion releases huge amounts of greenhouse gases into the atmosphere (including carbon oxides $\left(\mathrm{CO}, \mathrm{CO}_{2}\right)$, sulphur oxides $\left(\mathrm{SO}_{2}, \mathrm{SO}_{3}\right)$, nitrogen oxides $\left(\mathrm{NO}, \mathrm{NO} \mathrm{O}_{x}\right)$ ) and dust, ashes and soot. Transportation is a significant share of the air pollution, mainly wheel-based transportation.

The combustion process in diesel engine is very complex physico-chemically and varies in time. The process is accompanied by simultaneous exchange of heat and mass and chemical reactions.

The development of internal combustion engines is made towards meeting of the increasingly stringent requirements for toxic exhaust emissions, reduction of fuel consumption, and preservation of Earth's natural resources.

The problem to solve in modern diesel engines is the emission of toxic compounds. One way to reduce emissions is to use a catalytic converter positioned directly in the combustion chamber of an internal combustion engine.

The aim of this analysis is assessment of toxic emissions of a diesel engine with an internal catalyst. Qualitative assessment of engine emissions was determined by comparing test results of an engine with ceramic-ally coated valves against one with just conventional valves (commercial valves - without a ceramic coating). The study utilized a fourcylinder 1.9 TDI VW engine. It was expected that the use of glow plugs with an active coating would reduce the release of toxic compounds.
\end{abstract}

Keywords: catalyst, diesel engine, emissions

\section{Introduction}

In the era of rapid development of civilization, and thus the evolution of technology, the bar is also raised for the requirements that the modern engines must meet. These requirements apply not only to the produced power, fuel consumption, noise reduction, but also to the cleanliness of emissions. These forces designers to look for solutions that will result in meeting the norms imposed on toxic emissions. All of this is in search of limiting of production of toxins and neutralization of toxins that is produced $[1,3,4,5,6]$.

Automotive industry has a very diverse impact on the environment. You can divide it into beneficial effects, mainly sociological and civilization, and adverse effects such as air pollution from exhaust fumes, effects causing vibration and noise, or leaks [7, 8]. Subjects of environmental impact are primarily: motor vehicles (cars, trucks, buses, etc.), automotive factories, consumables 
supply plants (mining and refining), transport infrastructure (roads, fuel stations, garages, parking lots, handling services) $[2,9,10,11]$.

Given the fact that the internal combustion engine will remain as the automobiles' dominant source of power for a number of years to come, research work is necessary leading to a reduction of the toxic effect of exhaust on the environment. A certain segment of this work is to study the impact of active ceramic coatings (applied to the motor valves) on the exhaust emissions [12-18].

\section{The form of the internal combustion catalyst}

Treatment of exhaust gases in the catalytic afterburner is implemented in order to transform any harmful substances leaving the combustion chamber generated in the combustion process. Such gases are in whole or in part converted into substances harmless to human health and the environment. The main components of the catalyst converter are the ceramic carrier, the intermediate layer, the catalytically active coating. The catalyst is a substance that increases the rate at which a chemical reaction reaches equilibrium, it is not consumed itself in the process and its symbol does not participate in a stoichiometric equation. Typically, for considerably change, the reaction rate is a small amount of the catalyst is sufficient comparing to the amount of reacting substances.

This internal combustion catalyst is a catalytic substance applied to a portion or all of the walls forming the combustion space of a combustion engine, or just an element within that space - e.g. valves that were previously coated with a ceramic coating acting as the carrier substance.

To prevent corrosion and any peeling off the ceramic layer due to differences in thermal expansion between the materials an interlayer is introduced between the outer surface of the engine component and the ceramic layer.

Depending on the type, size and location of the catalyst, and also on the load and speed of the engine, the efficiency of the catalytic reactor in the individual stages can vary. The coating was performed on the active surface of the glow plugs. The disadvantage in such catalyst activation based on a glow plug is a small active surface, practically limited only to the tip of the plug placed in the combustion space. The advantage is the relatively high temperature of the catalyst, and its central location in the combustion space.

\section{The Test Lab}

Engine test has been carried out at the Department of Vehicle Engineering at the Technical University of Wroclaw on a test bench equipped with devices and instrumentation for monitoring of engine operation.

The test measured the degree of exhaust smoke opacity and the content of CO and NOx gases in the exhaust while the engine operated at different speeds and different loads. The measurements were first performed on an engine equipped with conventional valves and then, after adaptation, engine equipped with valves using a ceramic coating. The results of measurements were captured in special worksheets, and then data was represented in graphs that illustrate the magnitude of change that occurred after the engine upgrade. After the test of the engine equipped with conventional valves, the valves were replaced for coated ceramics. Coating was applied to a new set of valves due to excessive soot contamination and resulting carbonization on old valves during engine operation.

\section{Analysis and comparison of results}

Comparison of the results of measurements of an engine fitted with conventional valves against valves with active ceramic coating. Comparative studies were carried out for three different engine speeds, using a stepwise variable load. Contents of $\mathrm{CO}$ and NOx were measured in the exhaust gas and the degree of smoke opacity. 


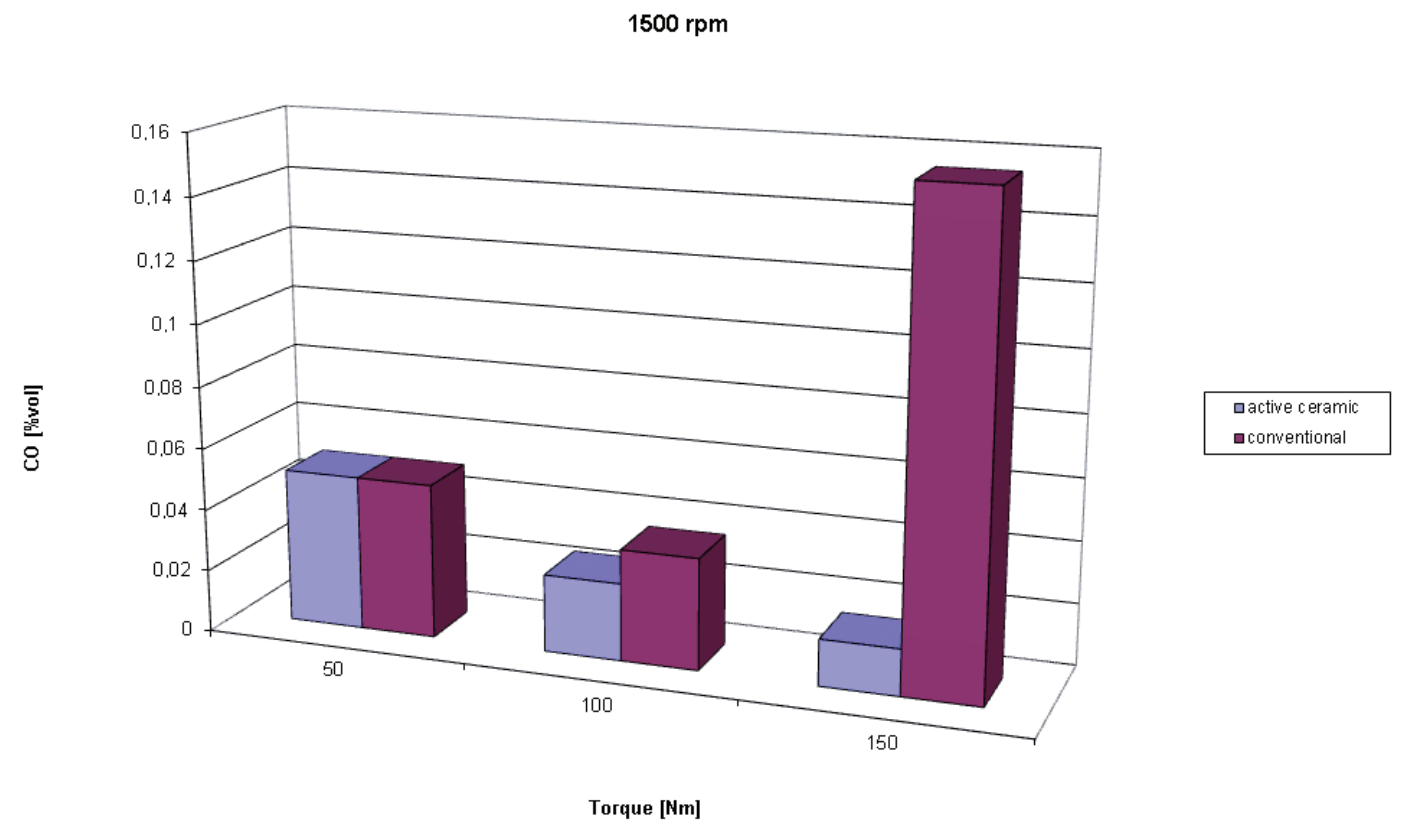

Fig. 1. Influence of load and types of valves on the CO content in the exhaust gas for VW 1.9 TDI at a speed of $1500 \mathrm{rpm}$

At a speed of $1500 \mathrm{rpm}$ - for conventional valves - load affects the increase of CO content in the exhaust gas, and so for $\mathrm{N}=100 \mathrm{Nm}$ is $0.036 \%$ and for $\mathrm{N}=150 \mathrm{Nm}$ increases to $0.155 \%$. The use of ceramic valves significantly reduced the $\mathrm{CO}$ content in the exhaust gas. In the worst case, when $\mathrm{N}=150 \mathrm{Nm} \mathrm{CO}$ content was $0.015 \%$, was therefore more than 10 times smaller than the most unfavourable case with conventional valves.

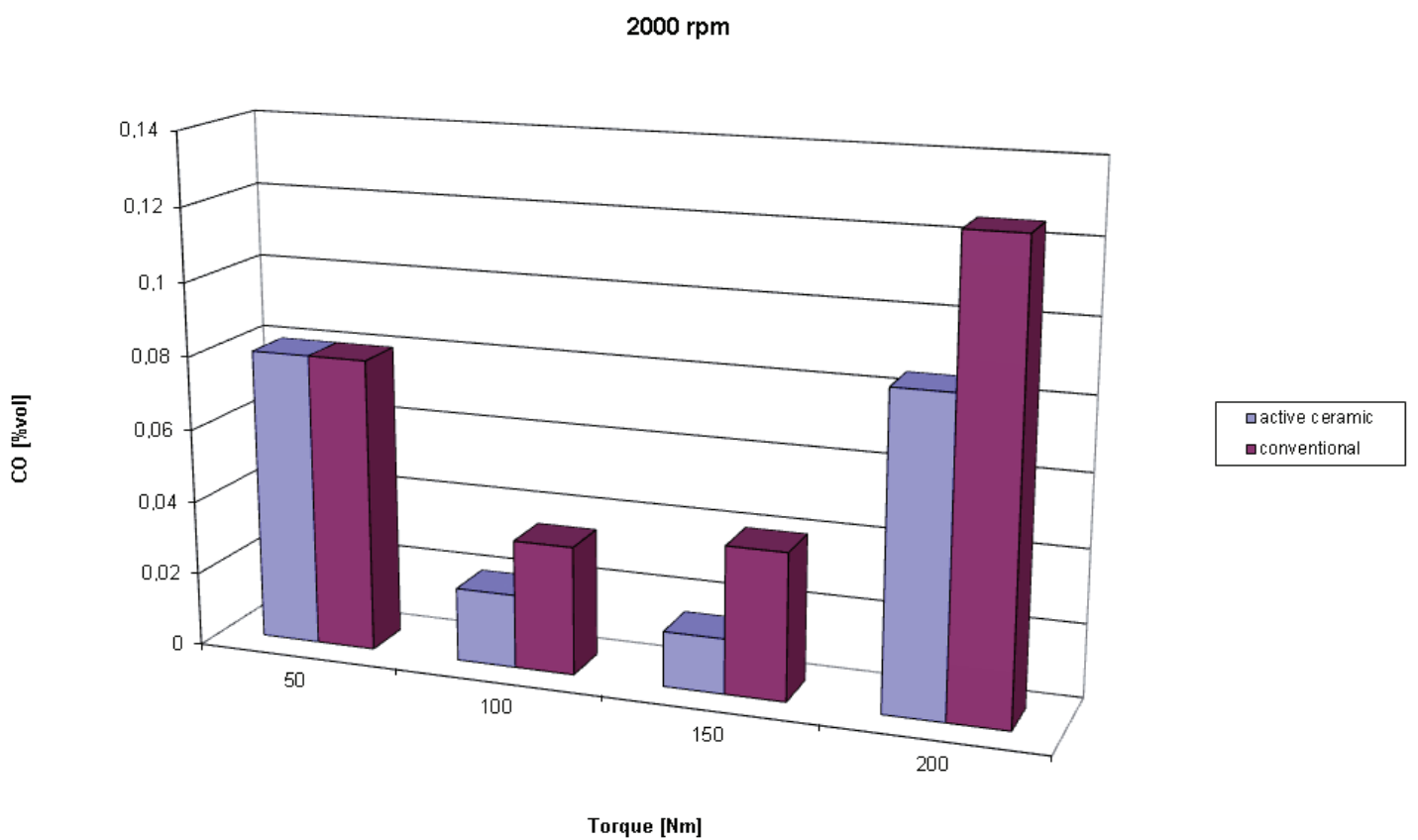

Fig. 2. Influence of load and types of valves on the CO content in the exhaust gas for VW 1.9 TDI at a speed of $2000 \mathrm{rpm}$

At the speed of $2000 \mathrm{rpm}$ - for conventional valves - an increase in load causes an increase in the $\mathrm{CO}$ emission at first, then emission decreases, and again increases with load. In the case of using ceramic valves, the relationship is similar. Generally, the use of ceramic valves significantly reduces the $\mathrm{CO}$ content in the exhaust gas. 


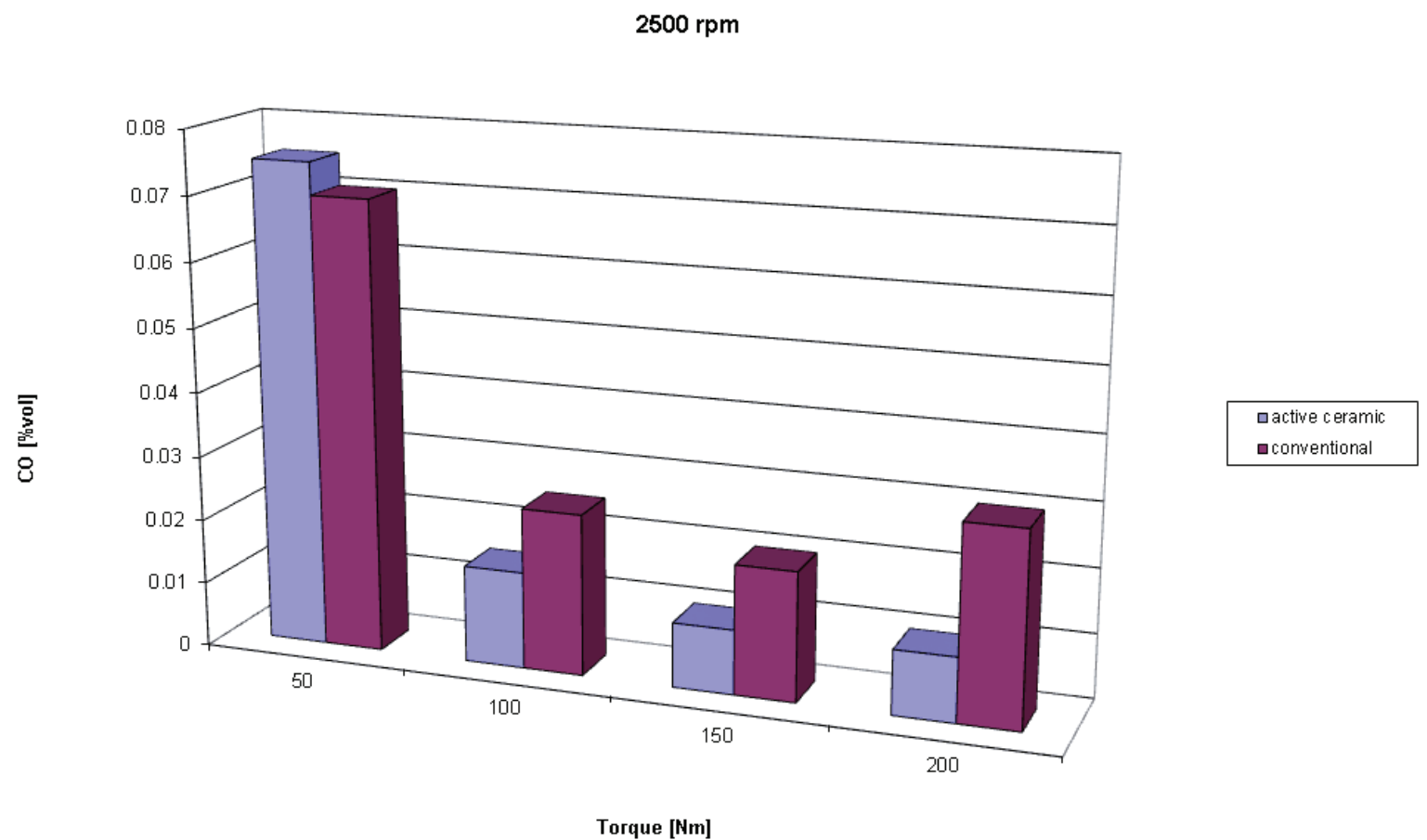

Fig. 3. Influence of load and types of valves on the CO content in the exhaust gas for VW 1.9 TDI at a speed of $2500 \mathrm{rpm}$

The increase in load causes at first increase in $\mathrm{CO}$ emission, then emission declines. From the graph, you can see that the use of ceramic valves significantly reduces the $\mathrm{CO}$ content in the exhaust gas.

$1500 \mathrm{rpm}$

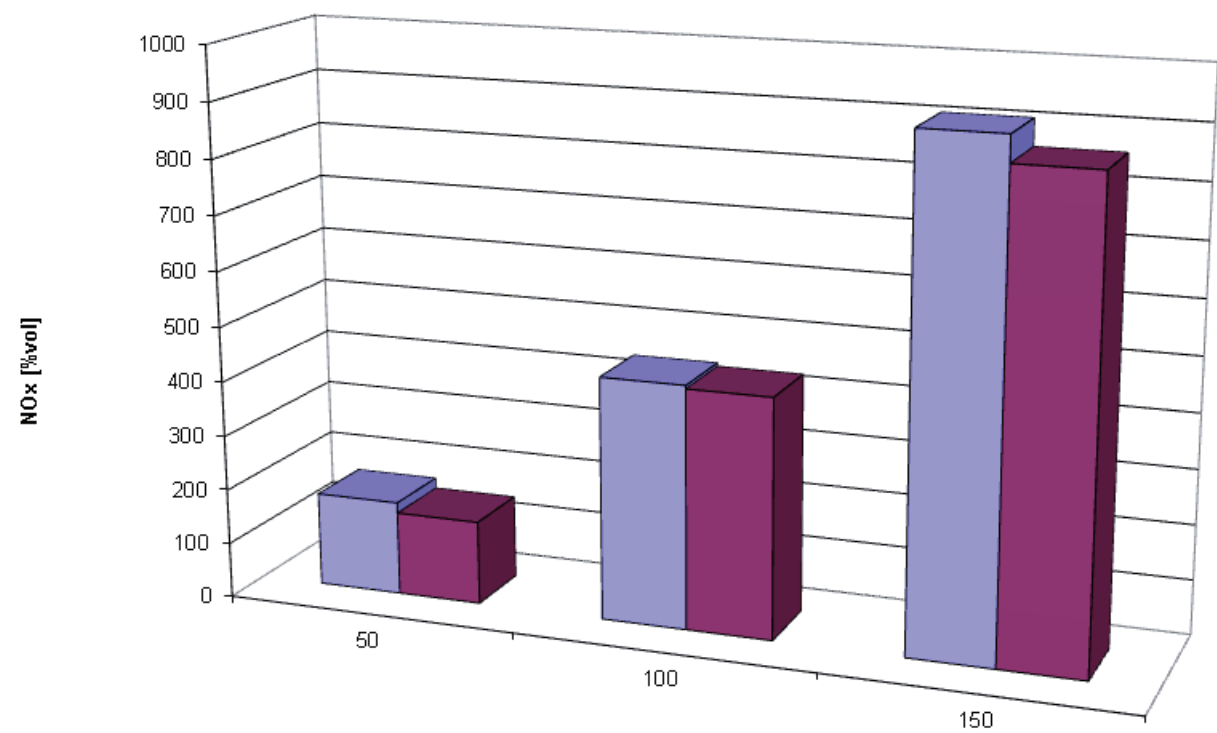

Torque [Nm]

Fig. 4. Influence of load and types of valves on the content of NOx in the exhaust gas for VW 1.9 TDI at a speed of $1500 \mathrm{rpm}$

The use of ceramic valves increases the $\mathrm{NO}_{\mathrm{x}}$ content as compared to conventional valves. This increase is quantitatively small. Both in the case of conventional valves, and ceramic, the load will significantly influence the level of $\mathrm{NO}_{\mathrm{x}}$ in the exhaust. 


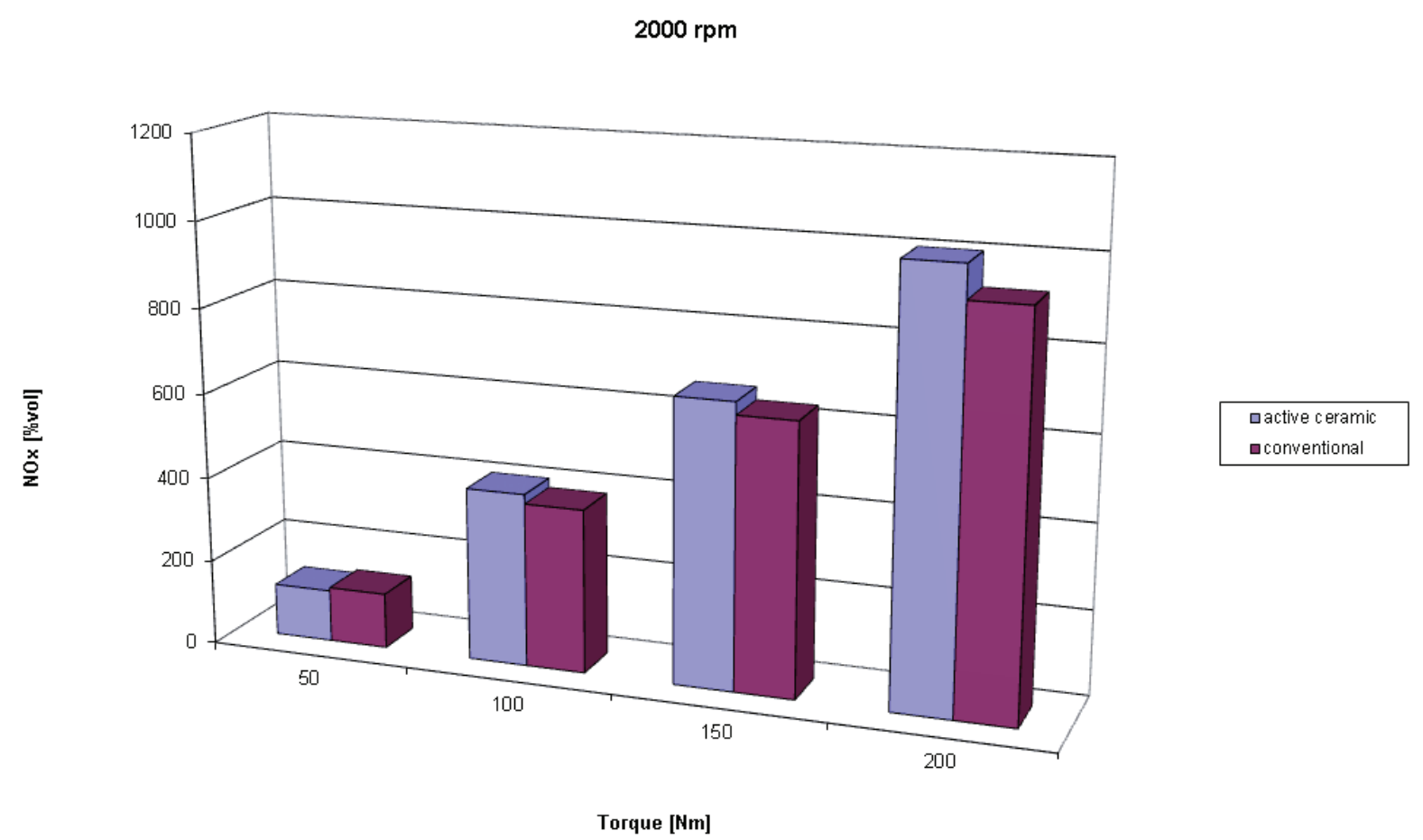

Fig. 5. Effect of load and types of valves on the content of NOx in the exhaust gas for VW 1.9 TDI at a speed of $2000 \mathrm{rpm}$

In the case of the rotational speed of $2000 \mathrm{rpm}$, the relation between the $\mathrm{NO}_{\mathrm{x}}$ content in the exhaust gas and the load and the type of valve is of a similar nature as with a speed of $1500 \mathrm{rpm}$. It has been observed that the type of plug has lest impact on the $\mathrm{NO}_{\mathrm{x}}$ emission, while the increase in speed from 1500 to $2000 \mathrm{rpm}$ results in a some insignificant increase in $\mathrm{NO}_{\mathrm{x}}$ in the exhaust.

$2500 \mathrm{rpm}$

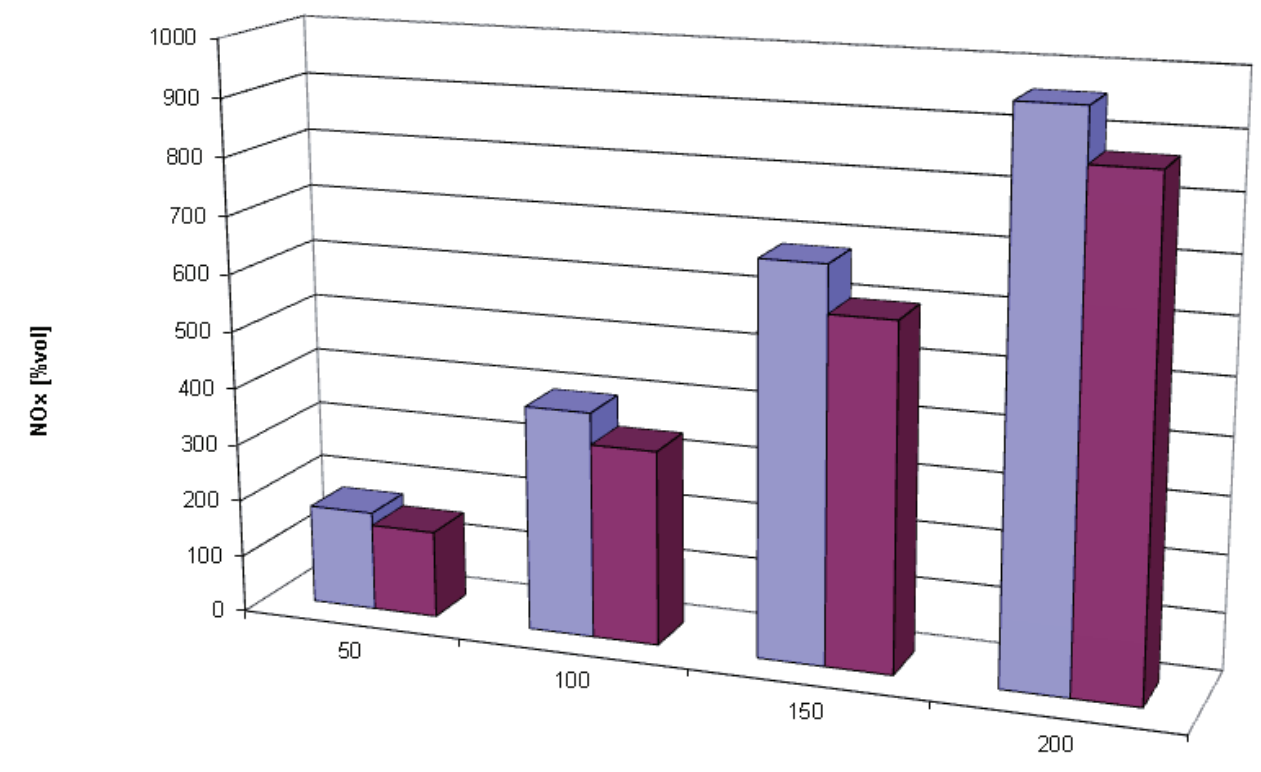

Torque [Nm]

Fig. 6. Influence of load and types of valves on the content of NOx in the exhaust gas for VW 1.9 TDI at a speed of $2500 \mathrm{rpm}$

At the engine speed of $2500 \mathrm{rpm}$, the relation between the $\mathrm{NO}_{\mathrm{x}}$ emission and the load and the type of valve is of a similar nature as at the speed of 1500 and $2000 \mathrm{rpm}$. 


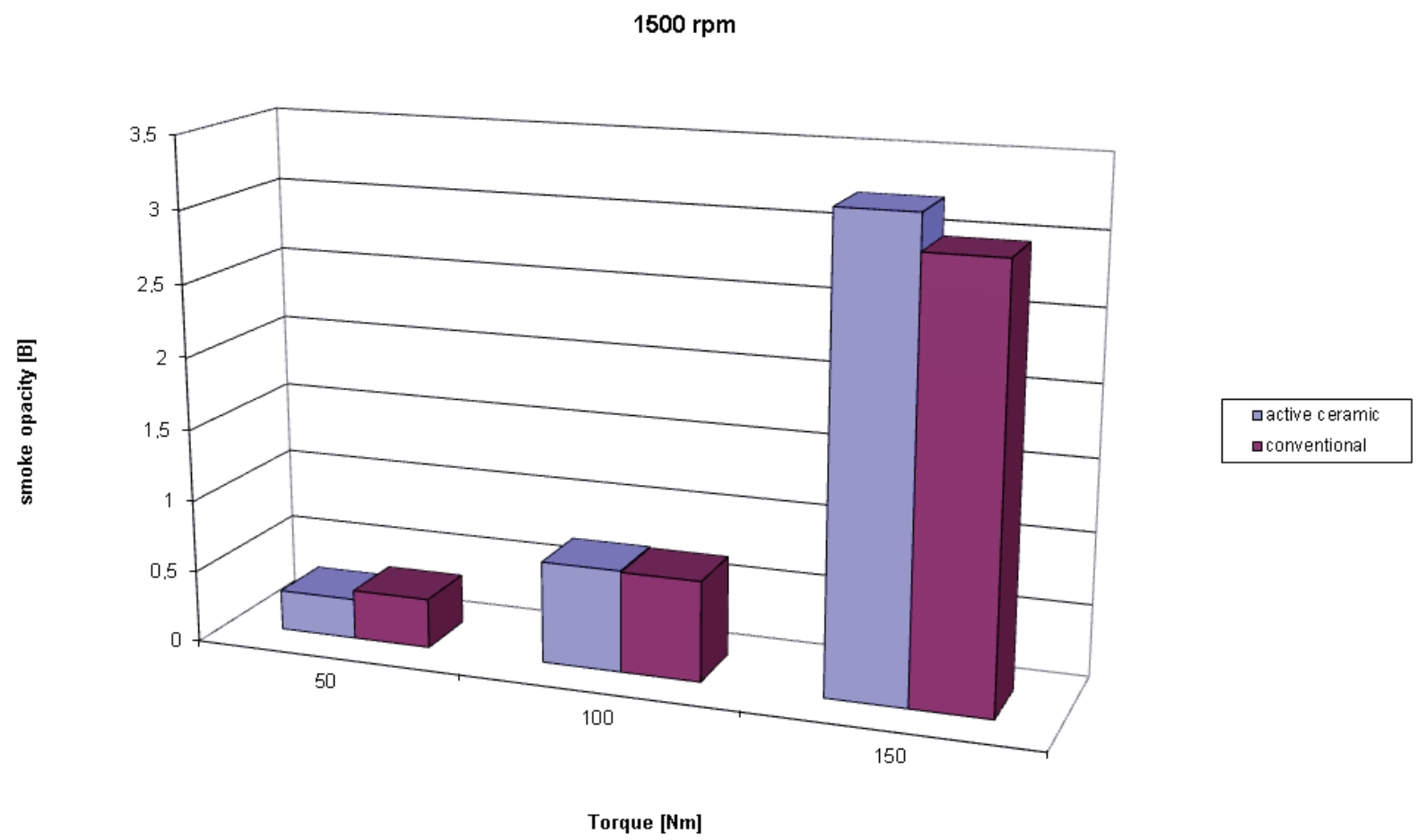

Fig. 7. Effect of load and types of valves on the degree of smoke opacity for VW 1.9 TDI at a speed of $1500 \mathrm{rpm}$

With the increase of the engine, load the smoke opacity increases. The effect of valve type on the degree of smoke opacity is not clear. The overall assessment is disturbed by the results of measurements at engine load torque of $150 \mathrm{Nm}$.

\section{$2000 \mathrm{rpm}$}

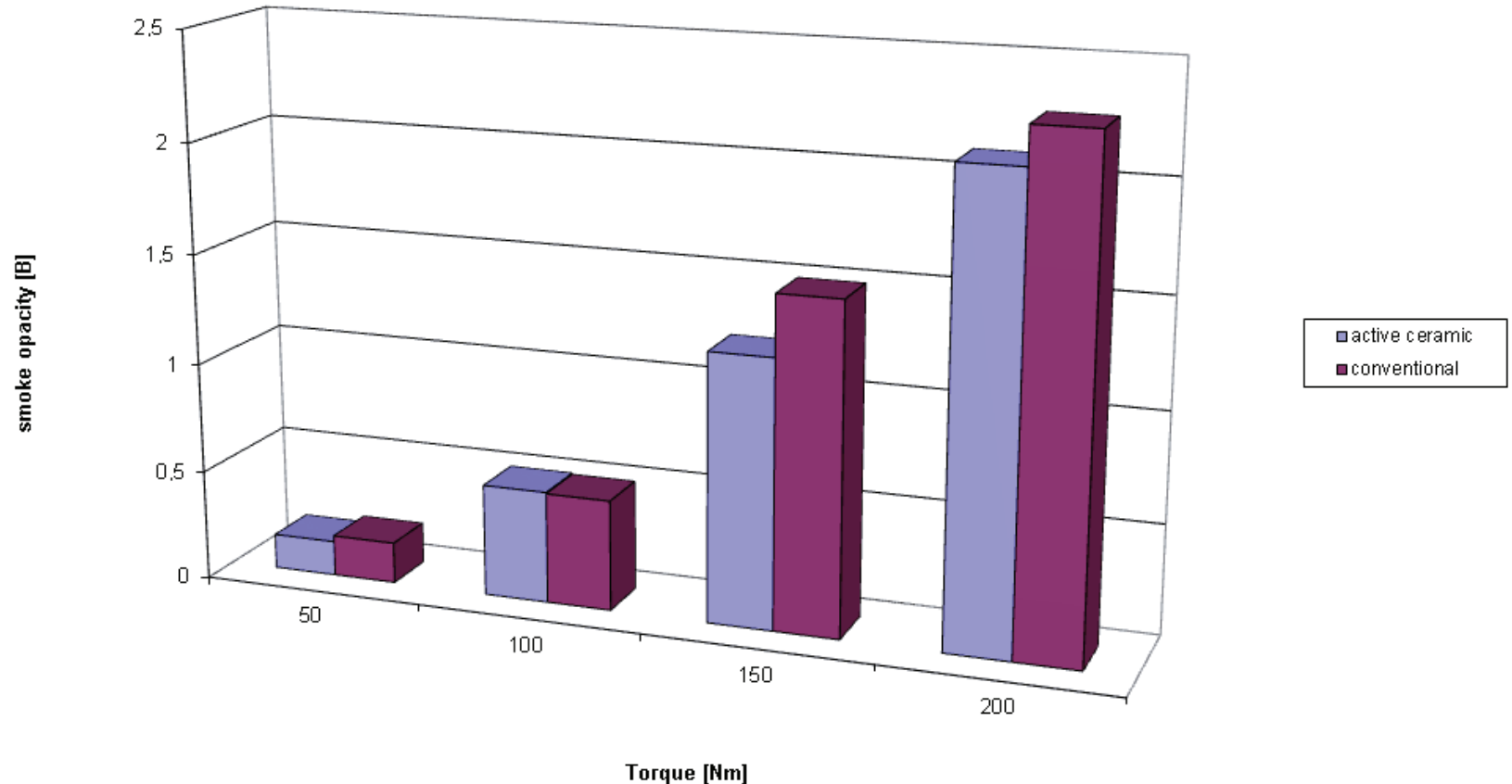

Fig. 8. Influence of load and types of valves on the degree of smoke opacity for VW 1.9 TDI at a speed of $2000 \mathrm{rpm}$

The graph reveals perfectly that the use of valves with active ceramic coating greatly reduces the degree of smoke opacity. 


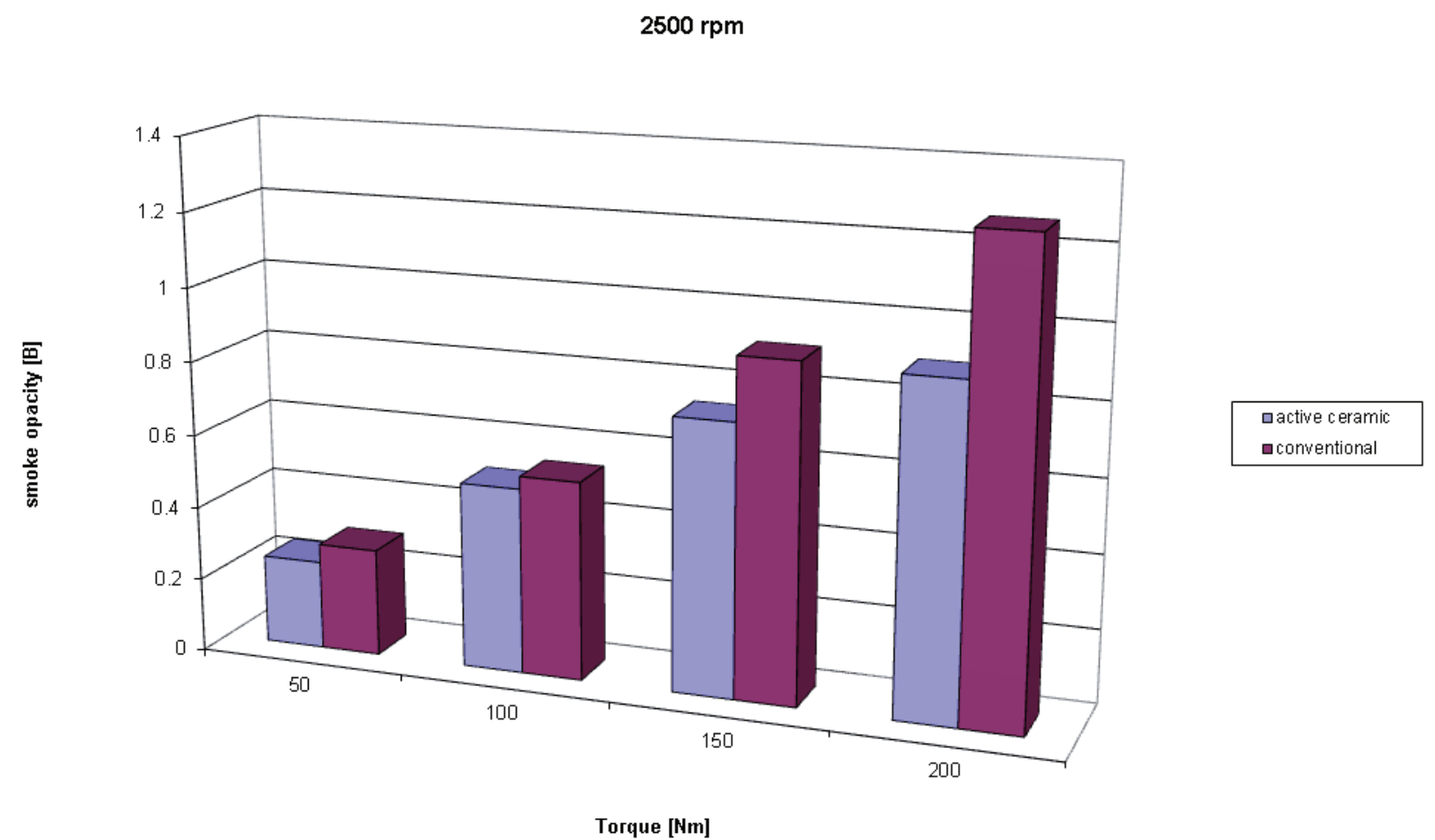

Fig. 9. Influence of load and types of valves on the degree of smoke opacity for VW 1.9 TDI at a speed of $2500 \mathrm{rpm}$

As the load increases the degree of smoke opacity at speeds of $\mathrm{n}=1500,2000$ and $2500 \mathrm{rpm}$ tends to increase. Clearly observable is the impact of rotational speed on the smoke. All in all: Higher rotational speed and the use of valves with active ceramic coating greatly reduce the degree of smoke opacity.

\section{Conclusion}

The following conclusions were reached based on the analysis of results:

Replacement of conventional valves, in the VW 1.9 TDI engine, with valves carrying active ceramic coating resulted in several-fold reduction of the $\mathrm{CO}$ content in the exhaust gas (up to 10 times at $\mathrm{n}=1500 \mathrm{rpm}$ and $150 \mathrm{Nm}$ load, and three times at $\mathrm{n}=2000 \mathrm{rpm}$ and a load of $200 \mathrm{Nm}$ ). There has been a slight increase in NOx emission in the exhaust gas within the measurement range and a reduction in smoke (the smoke opacity was generally lower, only on small engine speed and high load smoke was more intense).

A significant reduction in carbon monoxide content in the exhaust gas emitted from the engine was observed with an application of a modified ceramic coating on the valves as a result of the catalytic activity of this layer. It causes an improvement in the combustion adjacent to the walls of the engine, which leads to an overall reduction in the temperature at which oxidation reactions occur, as well as a catalyst, assisted process.

The catalytic layer located in the combustion chamber should also help to reduce the ignition temperature and a reduction in peak combustion temperature, which in turn should also manifest itself in decrease of the content of NOx in the exhaust. This phenomenon was observed in only one case, when $\mathrm{N}=100 \mathrm{Nm} \mathrm{n}=2500 \mathrm{rpm}$.

The study should be regarded as preliminary understanding on the suitability of the use of ceramics in diesel engines. Generally, it should be noted that the valves modified with a ceramic coating could have a significant positive effect on engine performance. However, this requires further complex research. 


\section{References}

[1] Janicka, A., Emisja zwiąków toksycznych silnika o zapłonie samoczynnym z katalizatorem wewnętrznym, Wrocław 2008.

[2] Merkisz, J., Ekologiczne problemy silników spalinowych, Wydawnictwo Politechniki Poznańskiej, Poznań 1998.

[3] Chłopek, Z., Pojazdy samochodowe, Ochrona środowiska naturalnego, WKi屯, Warszawa 2002.

[4] Rychter, T., Teodorczyk, A., Pojazdy samochodowe. Teoria silników tłokowych, WKiŁ, Warszawa 2002.

[5] Piotrowski, K., et al., Podstawy Toksykologii, WNT, Warszawa 2006.

[6] Warych, J., Oczyszczanie przemysłowych gazów odlotowych, PWN, Warszawa 1994.

[7] Haller, P., Jankowski, A., Kolanek, C., Walkowiak, W., Microemulsions as fuel for diesel engine, Journal of KONES, Vol. 19, No. 3, pp. 165-170, 2012.

[8] Sitnik, L., Dworaczyński, M., Haller, P., Water-carbohydron emulsions obtained by cavitation used for the fuelling of diesel engines, Archiwum Motoryzacji, Vol. 60, No. 2, 2013.

[9] Kaźmierczak, A., Silniki pojazdów samochodowych, REA, Warszawa 2010.

[10] Jankowski, A., Influence of chosen parameters of water fuel microemulsion on combustion processes, emission level of nitrogen oxides and fuel consumption of ci engine, Journal of KONES Powertrain and Transport, Vol. 18, No. 4, 2011.

[11] Jankowski, A., Sandel, A., Jankowska-Siemińska, B. Sęczyk, J. Measurement of drop size distribution in fuel sprays by laser methods, Journal of KONES Vol. 8 No. 3-4, pp. 334-345, 2001.

[12] Jankowski, A., Heat transfer in combustion chamber of piston engines, Journal of KONES Vol. 17 No. 1, pp. 187-197, 2010.

[13] Jankowski, A., Study of the influence of different factors on combustion processes (Part two), Journal of KONES Internal Combustion Engines 2009, Vo. 16, No. 3 pp. 135-140, 2009.

[14] Jankowski, A., Some aspects of heterogeneous processes of the combustion including two phases, Journal of KONES, Vol. 12, No. 1-2, pp. 121-134, 2005.

[15] Jankowski, A., Czerwinski, J., Memorandum of prof. A. K. Oppenheim and an example of application of the Oppenheim correlation $(O P C) *$ for the heat losses during the combustion in IC-engine, Journal of KONES, Vol. 17, No. 2, pp. 181-104, 2010.

[16] Jankowski, A., Study of the influence of different factors on combustion processes (Part one), Journal of KONES, Vol. 16, No. 1, pp. 209-216, 2009

[17] Jankowski, A., Laser research of fuel atomization and combustion process in the aspect of exhaust gases emission, Journal of KONES Powertrain and Transport, Vol. 15, No. 1, pp. 119- 126, 2008.

[18] Jankowski, A., Sandel, A., Seczyk, J., Jankowska-Sieminska, B., Some problems of improvement of fuel efficiency and emissions in internal combustion engines, Journal of KONES Internal Combustion Engines, Vol. 9, No. 3-4, pp. 333-356, 2002. 